УДК 342.951

DOI https://doi.org/10.32837/npnuola.v28i29.709

\title{
М. Є. Александров
}

\section{МІНІСТЕРСТВО ОБОРОНИ УКРАЇНИ ЯК СУБ'ЄКТ АДМІНІСТРАТИВНО-ПРАВОВОГО РЕГУЛЮВАННЯ У СФЕРІ ПАТРІОТИЧНОГО ВИХОВАННЯ}

Постановка проблеми. Від рівня патріотизму захисників залежить їх усвідомлення необхідності виконання бойових завдань та ступінь протистояння як фізичним, та і психологічним атакам ворога. Саме тому особливого значення набуває патріотичне виховання в секторі національної безпеки й оборони України, першим складовим суб'єктом якого є Міністерство оборони України (далі - Міноборони) [1].

Оцінка стану літератури. На сьогодні існує чимало досліджень, які визначають місце та роль держави в цілому, а також окремих органів державної влади в процесах патріотичного виховання. Зокрема, Е. Афонін, $€$. Бородін, М. Головатий, В. Князєв та ін. досліджували процеси формування та реалізації державної політики у цій сфері. Проблеми державної підтримки патріотичного виховання української молоді були предметом дослідження А. Коваля. Але, попри значний внесок зазначених авторів у розроблення питання державного регулювання у досліджуваній сфері, неохопленими на сьогодні залишаються питання адміністративно-правового регулювання патріотичного виховання, а також питання ролі та місця суб'єктів такого регулювання, зокрема Міноборони.

Мета. Метою дослідження є визначення місця та ролі Міноборони як суб'єкта адміністративно-правового регулювання патріотичного виховання. Для досягнення мети дослідження пропонуємо виконати такі наукові завдання:

- з'ясувати визначення суб'єктів адміністративно-правового регулювання;

- визначити характерні особливості, властиві суб'єктам адміністративно-правового регулювання;

- проаналізувати складники статусу Міноборони як суб’єкта адміністративно-правового регулювання у сфері патріотичного виховання;

- з'ясувати, яким чином Міноборони здійснює регулювання адміністративно-правових відносин у сфері патріотичного виховання.

Виклад основного матеріалу. Як зазначає К.С. Токарєва, до системи суб'єктів адміністративно-правового регулювання варто віднести таких суб'єктів, як держава, іiі органи та недержавні інституції, які реалізують повноваження у відповідній сфері адміністративно-правового

(C) Александров М. Є., 2021 
регулювання [2, с. 107]. Виділяючи окремий суб’єкт із системи суб’єктів адміністративно-правового регулювання в конкретній галузі суспільних відносин, В.Й. Розвадовський визначає його (суб'єкта) як складову частину системи державних органів (їх посадових та службових осіб), яка наділена державно-владними, розпорядчими та організаційними повноваженнями, за допомогою яких вона виконує завдання та здійснює реалізацію функцій державної політики [3, с. 92] у певній галузі. Як бачимо, принципові відмінності у наведених вище визначеннях стосуються повноважень та дії зазначених суб’єктів, оскільки недержавні інституції не можуть бути наділеними державно-владними повноваженнями.

M.С. Козирєв дотримується думки, що суб’єктом адміністративно-правового регулювання можуть бути як органи, наділені владними повноваженнями, так і органи та установи, що таких повноважень не мають [4, с. 3]. Натомість В.К. Колпаков відстоює ідею керуючого впливу суб'єктів адміністративно-правового регулювання, наголошуючи на можливості такого суб'єкта впливати на об'єкт [5, с. 9].

Щоб розв'язати це питання, пропонуємо звернутися до визначення адміністративно-правового регулювання. Так Ю.А. Козаченко, досліджуючи адміністративно-правове регулювання забезпечення прав пацієнта, надає таку дефініцію: «<..> цілеспрямований владно-організуючий вплив органів управління в межах їх повноважень на впорядкування суспільних відносин» [6, с. 17]. О.О. Сурілова визначає адміністративно-правове регулювання у сфері використання і охорони надр як вплив уповноважених органів державної влади та місцевого самоврядування на суспільні відносини [7, с. 21]. Таким чином, ключовим в адміністративно-правовому регулюванні є вплив, який здійснюється на відносини у певній сфері, для чого суб’єкти такого регулювання мають бути наділені владними й організаційними повноваженнями. Отже, суб'єкти адміністративно-правового регулювання у сфері патріотичного виховання - це органи, наділені відповідними владними й організаційними повноваженнями, що здійснюють вплив на суспільні відносини у сфері патріотичного виховання.

Що стосується характеристики суб'єктів адміністративно-правового регулювання, то в юридичній літературі для об’єднання усіх складових характеристик найчастіше застосовується термін «статус». Н.В. Гречанюк до складників статусу відносить завдання та цілі, повноваження, компетенцію, відповідальність, порядок формування та процедуру діяльності органів тощо [8, с. 62]. На думку I.M. Риженко, обов’язковими ознаками адміністративно-правового статусу суб'єкта є сукупність його прав і обов'язків, а також правосуб'єктність, що визначені відповідними адміністративно-правовими нормами [9, с. 532]. Отже, для з'ясування статусу Міноборони як суб'єкта адміністративно-правового регулювання у сфері патріотичного виховання необхідно проаналізувати нормативно-правові акти, які визначають зміст діяльності, структуру прав, обов'язків та відповідальності зазначеного міністерства.

Міноборони здійснює свою діяльність згідно з Положенням про Міністерство оборони України, яке затверджене відповідною постановою Кабінету Міністрів України [10]. Міноборони є головним органом у систе- 
мі центральних органів виконавчої влади, який забезпечує формування та реалізує державну політику з питань національної безпеки у воєнній сфері, сферах оборони і військового будівництва у мирний час та протягом особливого періоду [10]. У підпорядкуванні Міноборони перебувають Збройні сили України (ЗСУ) та Державна спеціальна служба транспорту (ДССТ). У сфері патріотичного виховання Міноборони здійснює заходи щодо розвитку культури і духовності у Збройних силах, а також щодо військово-патріотичного виховання громадян [10].

Також Міноборони розробляє в установленому порядку Стратегію воєнної безпеки України і зміни до неї та бере участь у підготовці і періодичному уточненні Стратегії національної безпеки України, доктрин, концепцій, стратегій і програм у сфері національної безпеки [10]. Відповідно до Стратегії національної безпеки України «Безпека людині - безпека країні» одним із шляхів зміцнення бойового потенціалу ЗСУ є модернізація системи військово-патріотичного виховання молоді [11].

Серед основних функцій Міноборони, які визначені Законом України «Про оборону України», також $є$ функції з проведення державної військової кадрової політики та забезпечення розвитку військової освіти і науки, зміцнення дисципліни, правопорядку та виховання особового складу [12]. Оскільки відповідно до Концепції виховної роботи у Збройних силах та інших військових формуваннях України військово-патріотичне виховання $є$ складовою частиною інформаційно-пропагандистського забезпечення виховної роботи [13], Міноборони в межах своєї функції виховання особового складу здійснює також регулювання військово-патріотичного виховання.

Відповідно до Закону України «Про військовий обов’язок і військову службу» на Міноборони покладена відповідальність за організацію та проведення підготовки громадян України до військової служби, складовою частиною якої є патріотичне виховання [14].

Крім того, Міноборони є учасником заходів щодо національно-патріотичного виховання. Ще у 2015 році у рамках Указу Президента України «Про заходи щодо поліпшення національно-патріотичного виховання дітей та молоді» на Міноборони було покладене завдання розробити за три місяці спільний план невідкладних заходів, спрямованих на налагодження взаємодії у питаннях національно-патріотичного виховання допризовної молоді та популяризації військової служби [15]. У 2017-2021 роках Міноборони було учасником плану заходів з відзначення 100-річчя подій Української революції 1917-1921 років та вшанування пам'яті ії учасників [16].

У 2020 році Кабінет Міністрів України затвердив новий план дій шодо реалізації Стратегії національно-патріотичного виховання на 2020-2025 роки [17]. Відповідно до затвердженого плану Міноборони є відповідальним за виконання 18 з 33 заходів щодо реалізації плану, що охоплюють такі напрями: удосконалення нормативно-правової бази щодо національно-патріотичного виховання; упорядкування та вдосконалення системи військово-патріотичного виховання; організацію та координацію інформаційно-просвітницької роботи у сфері національно-патріотичного виховання; забезпечення належної організації науково-дослідної та методичної роботи у сфері національно-патріотичного виховання; 
забезпечення скоординованої діяльності у сфері національно-патріотичного виховання.

Як бачимо, Міноборони не тільки бере участь в безпосередній реалізації заходів, а й удосконалює нормативно-правову базу щодо національно-патріотичного виховання, зокрема й адміністративно-правові норми.

У червні 2021 року була затверджена Державна цільова соціальна програма національно-патріотичного виховання на період до 2025 року [18], виконавцем якої $€$, зокрема, Міноборони. Міноборони є відповідальним за виконання таких заходів: збільшення чисельності молоді, готової до виконання обов'язку із захисту незалежності та територіальної цілісності України; формування розуміння і підтримки громадянами України державної політики у сфері євроатлантичної інтеграції та практичних кроків щодо зближення з НАТО на основі українських національних цінностей; формування оборонної свідомості населення України; популяризацію і підвищення престижу військової та спеціальної державної служби (в тому числі й розвиток військово-прикладного і службово-прикладного спорту, військової науково-технічної творчості та інновацій); сприяння створенню та реалізації нової системи військово-патріотичного виховання та громадського сприяння безпеці та обороні України [18].

Крім того, важливою складовою частиною адміністративно-правового статусу Міноборони як суб'єкта адміністративно-правового регулювання у сфері патріотичного виховання $є$ видання відповідних наказів, а також здійснення організації і контролю за їх виконанням [10]. Накази Міноборони, видані в межах повноважень, передбачених законом, є регуляторними актами, обов'язковими для виконання центральними органами виконавчої влади, їх територіальними органами, місцевими держадміністраціями, органами влади Автономної Республіки Крим, органами місцевого самоврядування, підприємствами, установами і організаціями незалежно від форми власності і громадянами [10]. У сфері національно-патріотичного виховання наказами Міноборони були затверджені такі документи: «Положення про організацію та проведення у Збройних силах України Міжнародного конкурсу з української мови імені Петра Яцика» (Наказ Міністерства оборони України від 29.08.2014 р. № 580), «Положення про організацію діяльності військових музеїв, музеїв (кімнат) бойових традицій у Збройних силах України» (Наказ Міністерства оборони України від 17.07.2018 р. № 343) [19].

Очільником Міноборони є Міністр, який наділений відповідними повноваженнями. Зокрема, Міністр оборони організовує та контролює виконання в Міноборони Конституції України, законів України, актів Президента України та Кабінету Міністрів України [10] щодо заходів національно-патріотичного і військово-патріотичного виховання. Також Міністр оборони визначає пріоритети роботи Міноборони і відповідає за формування державної політики у сфері оборони, військову кадрову політику, всебічне забезпечення життєдіяльності, функціонування, розвиток та застосування Збройних сил [10], враховуючи потреби національно патріотичного виховання. Так, Міністр оборони затвердив Концепцію воєнної історії України, метою і завданням якої $€$ національно-патріотичне виховання 
широких верств українського суспільства. Ця Концепція, на думку розробників, надасть змогу використовувати здобуті воєнно-історичні знання для подальшого розвитку Збройних сил України, їх підготовки та військово-патріотичного виховання [20].

Висновки. Отже, Міноборони як суб’єкт адміністративно-правового регулювання у сфері патріотичного виховання наділене відповідними владними й організаційними повноваженнями, правами та обов’язками, за допомогою яких воно впливає на суспільні відносини у сфері патріотичного виховання. Реалізація такого впливу здійснюється як Міноборони в цілому, так і окремими його посадовими особами (Міністром оборони) шляхом здійснення заходів щодо військово-патріотичного виховання громадян, розроблення в установленому порядку Стратегії воєнної безпеки України, забезпечення процесів виховання особового складу ЗСУ, відповідальності за підготовку громадян до військової служби, затвердження Концепції воєнної історії України тощо. Перелічені заходи мають на меті військово-патріотичне виховання як військовослужбовців і військовозобов'язаних, так і широких верств населення. Складники статусу Міноборони як суб'єкта адміністративно-правового регулювання у сфері військово-патріотичного виховання закріплені законами України, указами Президента України, постановами та розпорядженнями Кабінету Міністрів України.

\section{Література}

1. Про національну безпеку України : Закон України від 21 червня 2018 року № 2469-VIII. URL: https: / / zakon.rada.gov.ua/laws/show/2469-19\#Text (дата звернення: 29.10.2021).

2. Токарєва К.С. Суб̆єкти адміністративно-правового регулювання медіації. Наукові записки. Серія «раво». С. 106-111.

3. Розвадовський В.Й. Система суб’єктів адміністративно-правового регулювання правовідносин у транспортній сфері. Вісник Національного університету внутрішніх справ. 2004. Вип. 25. С. 91-100.

4. Козырев М.С. Субъекты административно-правового регулирования : лекция учебной дисциплины «Государственное управление и публичная политика». Москва, 2016. 39 с.

5. Колпаков В.К. Адміністративне право України : підручник. Київ : Юрінком Інтер, 1999. 736 с.

6. Козаченко Ю.А. Адміністративно-правове регулювання забезпечення прав пацієнта в Україні : автореф. дис. ... канд. юрид. наук : 12.00 .07 ; Національний юридичний університет ім. Ярослава Мудрого. Харків, 2016. 24 с.

7. Сурілова О.О. Адміністративно-правове регулювання у сфері використання і охорони надр : автореф. дис. ... докт. юрид. наук : 12.00 .07 ; Держ. ВНЗ Запоріз. нац. ун-т М-ва освіти і науки України. Запоріжжя, 2017. 34 с.

8. Гречанюк Н.В. Статус суб'єктів адміністративно-правового регулювання становлення ринку землі в Україні. Науковий вісник Міжнародного гуманітарного університету. Серія «Юриспруденція». 2014. № 9-1. С. 62-64.

9. Риженко I.M. Статус суб'єктів адміністративно-правового захисту власності суб'єктів господарювання в Україні. Форум права. 2009. № 3. С. 531-537.

10. Про затвердження Положення про Міністерство оборони України : Постанова Кабінету Міністрів України від 26 листопада 2014 р. № 671 (у редакції Постанови Кабінету Міністрів України від 19 жовтня 2016 р. № 730). URL: https://zakon.rada.gov.ua/laws/show/ 671-2014-\%D0\%BF\#Text (дата звернення: 01.11.2021).

11. Про рішення Ради національної безпеки і оборони України від 14 вересня 2020 року «Про Стратегію національної безпеки України»: Указ Президента України від 14 вересня 2020 року № 392/2020. URL: https://zakon.rada.gov.ua/laws/show/392/2020\#n7 (дата звернення: 01.11.2021).

12. Про оборону України : Закон України від 6 грудня 1991 року № 1932-XII. URL: https://zakon.rada.gov.ua/laws/show/1932-12\#Tехt (дата звернення: 01.11.2021). 
13. Про Концепцію виховної роботи у Збройних силах та інших військових формуваннях України : Указ Президента України від 4 вересня 1998 року № 981/98. URL: https://zakon.rada.gov.ua/ laws/show/981/98\#Text (дата звернення: 01.11.2021).

14. Про військовий обов'язок і військову службу : Закон України від 25 березня 1992 року № 2232-XII. URL: https://zakon.rada.gov.ua/laws/show/2232-12\#Text (дата звернення: $01.11 .2021)$.

15. Про заходи щодо поліпшення національно-патріотичного виховання дітей та молоді : Указ Президента України від 12 червня 2015 року № 334/2015. URL: https:/ / zakon.rada.gov. ua/ laws/show/334/2015\#Text (дата звернення: 01.11.2021).

16. Про затвердження плану заходів з відзначення 100-річчя подій Української революції 1917-1921 років та вшанування пам'яті ії учасників на період до 2021 року : Розпорядження Кабінету Міністрів України від 26 жовтня 2016 р. № 777-p. URL: https:/ / zakon.rada.gov.ua/ laws/show /777-2016-\%D1\% 80\#Text (дата звернення: 01.11.2021).

17. Про затвердження плану дій щодо реалізації Стратегії національно-патріотичного виховання на 2020-2025 роки : Постанова Кабінету Міністрів України від 09 жовтня 2020 року № 932. URL: https:/ / zakon.rada.gov.ua/laws/show/932-2020-\%D0\%BF\#Text (дата звернення: 01.11.2021).

18. Про затвердження Державної цільової соціальної програми національно-патріотичного виховання на період до 2025 року та внесення змін до деяких постанов Кабінету Міністрів України : Постанова Кабінету Міністрів України від 20 червня 2021 року № 673. URL: https:/ / zakon.rada.gov.ua/laws/show/673-2021-\%D0\%BF\#Text (дата звернення: 01.11.2021).

19. Нормативно-правова база військово-патріотичного виховання Міністерства оборони України. URL: https://www.mil.gov.ua/diyalnist/vijskovo-patriotichna-robota/normativnopravova-baza-vijskovo-patriotichnogo-vihovannya/ (дата звернення: 01.11.2021).

20. Концепція воєнної історії України : затверджена Міністром оборони України 08 грудня 2017 року. URL: https:/ / dovidnykmpz.info/ipz/kontseptsiia-voiennoi-istorii-ukrainy-za/ (дата звернення: 01.11.2021).

\section{Анотація \\ Александров М. Є. Міністерство оборони України як суб'єкт адміністративно- правового регулювання у сфері патріотичного виховання. - Стаття.}

У статті розглянуто особливості статусу Міністерства оборони України як суб’єкта адміністративно-правового регулювання у сфері патріотичного виховання. Патріотичне виховання громадян України сьогодні є важливим завданням державної політики, до виконання якого залучені органи державної влади, зокрема й у сфері національної безпеки і оборони України.

Актуальність теми зумовлена реалізацією Стратегії національно-патріотичного виховання на 2020-2025 роки, для успішного виконання завдань якої необхідно розробити усі питання, що стосуються патріотичного виховання (зокрема, адміністративно-правовий статус його учасників). Автор на основі аналізу наукової літератури визначає, які органи та посадові особи можуть бути суб'єктами адміністративно-правового регулювання, а також окреслює складники статусу таких суб'єктів, до яких належать повноваження, права, обов'язки та відповідальність таких суб'єктів. Застосовуючи метод документального аналізу, автор на основі чинних нормативно-правових актів визначає повноваження, які Міністерство оборони України має у сфері адміністративно-правового регулювання досліджуваної галузі; аналізує завдання відомства щодо військово-патріотичного та національно-патріотичного виховання; наводить приклади участі Міністерства оборони України в адміністративно-правовому регулюванні патріотичного виховання.

Наукова новизна дослідження полягає у розробленні авторського визначення суб'єктів адміністративно-правового регулювання у сфері патріотичного виховання як органів, що наділені відповідними владними й організаційними повноваженнями, за допомогою яких вони впливають на суспільні відносини у сфері патріотичного виховання.

У висновках автор на підставі проведеного дослідження окреслює коло повноважень Міністерства оборони України щодо адміністративно-правового регулювання у сфері патріотичного виховання на підставі чинних нормативно-правових актів. Подальше дослідження 
можливе за напрямом визначення місця та ролі Міністерства оборони України в системі суб’єктів адміністративно-правового регулювання у сфері патріотичного виховання.

Ключові слова: статус суб'єктів адміністративного права, адміністративно-правовий статус, повноваження, національно-патріотичне виховання, військово-патріотичне виховання, нормативно-правові акти.

\section{Summary}

Aleksandrov M. Y. Ministry of Defense of Ukraine as a subject of administrative and legal regulation in the field of patriotic education. - Article.

The article considers the peculiarities of the status of the Ministry of Defense of Ukraine as a subject of administrative and legal regulation in the field of patriotic education. Patriotic education of the citizens of Ukraine today is an important task of state policy. There are public authorities in the field of national security and defense of Ukraine, which involved in implementation of policy of patriotic education.

The urgency of the topic is due to the implementation of the Strategy of national-patriotic education for 2020-2025. It is necessary to develop all issues related to patriotic education, including the administrative and legal status of its participants, for the successful implementation of this Strategy. The authors analysed scientific literature and determined which authorities and officials can be the subjects of administrative and legal regulation, outline the components of the status of such entities, which include the powers, rights, duties and responsibilities of such entities. Authors applying the method of documentary analysis and determined the powers that the Ministry of Defense of Ukraine has in the field of administrative and legal regulation of the study area, analyze the department's tasks of military-patriotic and national-patriotic education, and give examples of the Ministry of Defense Of Ukraine's participant in the administrative and legal regulation of patriotic education.

The scientific novelty of the study is to develop an author's definition of the subject of administrative and legal regulation in the field of patriotic education as authority's bodies endowed with appropriate governmental and organizational powers, with the help of influencing on public relations in the field of patriotic education.

In the conclusions, the authors on the basis of the research outline the scope of powers of the Ministry of Defense of Ukraine regarding administrative and legal regulation in the field of patriotic education on the basis of current regulations. Further development of the study is possible in the direction of determining the place and role of the Ministry of Defense of Ukraine in the system of subjects of administrative and legal regulation in the field of patriotic education.

Key words: status of subjects of administrative law, administrative-legal status, powers, national-patriotic education, military-patriotic education, normative-legal acts. 